\title{
Health considerations of the rehabilitation of illegally traded houbara bustards Chlamydotis undulata macqueenii in the Middle East
}

\author{
Tom Bailey, Christu-Das Silvanose, Jesus Naldo, Olivier Combreau, Frederic Launay, Ulrich Wernery, \\ Joerg Kinne, Richard Gough and Ruth Manvell
}

\begin{abstract}
There is a large illegal trade in trapped houbara bustards Chlomydotis undulata macqueenii, which are smuggled into the Middle East for falconry. Mortality is high and is associated with poor transport conditions, malnutrition, overcrowding and exposure to multiple infectious diseases, in particular aspergillosis, avian pox and paramyxovirus type 1 virus. Other pathogens include Salmonella sp., Pscudomonas sp., Trichomonas sp., intestinal endoparasites, avian leucosis, reovirus, adeno-
\end{abstract}

virus, paramyxovirus type 2 and Chlamydia sp. Various regional initiatives have been initiated to confiscate and rehabilitate illegally trapped birds. This paper reviews the causes of morbidity and mortality seen in illegally traded houbara bustards and provides health recommendations for those involved in rehabilitation.

Keywords Health, houbara bustard, illegal trade, Middle East, rehabilitation.

\section{Introduction}

The houbara bustard Chlamydotis undulata macqueenii has a high conservation profile because it is the traditional quarry of falconers in Arabia and a number of regional conservation projects have been initiated by influential Arab falconers to safeguard both the bustard and their tradition (Launay et al., 1999). There are few reliable data on the exact status of houbara bustard populations in the wild, but they are generally considered to have declined over most of their range during the last few decades for the following reasons: overgrazing, overhunting, agricultural development and human disturbance (Collar, 1996; Goriup, 1997). Although the houbara bustard has been downlisted from Vulnerable to Least Concern in the 1996 Red List of Endangered Animals (IUCN, 1996), a recent review of the world status of the houbara bustard by Goriup (1997) considered that the C. $u$. macqueenii population should be considered as 'Near Threatened'.

Tom Bailey (corresponding author) Environmental Research and Wildlife Development Agency, National Avian Research Center, PO Box 45553, Abu Dhabi, United Arab Emirates. E-mail: tabailey@erwda.gov.ae

Christu-Das Silvanose, Jesus Naldo, Olivier Combreau and Frederic Launay Environmental Research and Wildlife Development Agency, National Avian Research Center, PO Box 45553, Abu Dhabi. United Arab Emirates.

Ulrich Wernery and Joerg Kinne Central Veterinary Research Laboratory, P.O. Box 597, Dubai, United Arab Emirates.

Richard Gough and Ruth Manvell Central Veterinary Laboratory, New Haw, Weybridge, Surrey, UK.

Revised manuscript accepted for publication 20 May 2000
There is a large illegal trade in free-living houbara bustards, trapped in Pakistan, Iran and Afghanistan, which are exported to the Middle East (Fig. 1) where they are used by some falconers to train their falcons. It has been suggested that 4000-7000 houbaras are traded in this way from Pakistan each year (Goriup, 1997), while accurate information on the flow of birds from other countries is unknown. The mortality of the birds transported to the Middle East is high and entire shipments can die after arrival in Gulf countries. Poor husbandry, crowded transport conditions, exposure to infectious diseases carried by domestic birds, and insufficient food and water are responsible for the majority of deaths (Bailey, 1998a). This trade may have more impact on the status of the houbara bustard than direct hunting with falcons.

The United Arab Emirates (UAE) is a signatory to the Convention on International Trade in Endangered Species (CITES) of Wild Fauna and Flora and although the importation of free-living houbara bustards was banned in 1993, illegal trade continued relatively unimpeded (Anon., 1993). In 1998, initiatives were taken in Abu Dhabi and Sharjah to confiscate illegally imported houbara bustards when they entered the UAE, while government agencies in Pakistan actively confiscate birds as they are smuggled out of the country through air and sea ports. Attempts to rehabilitate and release these birds back into suitable habitats have also been initiated in Pakistan (Ahmed, 1997) and in the $\mathrm{UAE}$ at the National Avian Research Center (NARC).

Although some data concerning the morbidity, mortality and serology of imported houbara bustards during 1992-94 have been previously presented (Bailey et al., 1996a,b,c), a comprehensive review of the infectious 
diseases of these birds in relation to their medical rehabilitation is lacking. Exposure to infectious diseases is an important consideration for those agencies charged with the rehabilitation of illegally traded houbara bustards into the wild or into captive breeding projects (White \& Morzenti, 1997; IUCN, 2000). The purpose of this paper is to: 1) review data from 1992 to 1999 concerning the diseases that occur in smuggled bustards; 2) determine the relevance of these diseases to the quarantine and rehabilitation process; and 3) provide medical recommendations for those involved with quarantine and rehabilitation.

\section{Disease investigation}

The birds

A total of 596 live and 179 dead houbara bustards was examined by NARC personnel between 1992 and 1999. Birds were examined at the following sites: 1) Al Ain Zoo quarantine unit, UAE; 2) NARC quarantine unit, UAE; and 3) Houbara Foundation International Re- habilitation Centre, Pakistan. Although the majority of birds were suspected to come from Pakistan, some birds originated from Iran. It is also known that some birds are smuggled into the UAE with falconry parties that have hunted in Iraq, Afghanistan and Iran. Relevant post-mortem, clinical, endoparasite, haemoparasite and serological data from smuggled birds between 1992 and 1994 (Bailey et al., 1996a,b,c; Howlett et al., 1996; Jones et al., 1996) were also considered in this review.

\section{Health monitoring procedures}

Clinical and post-mortem examinations on live and dead birds were conducted following methods described by Bailey (1998a) to determine causes of morbidity and mortality, respectively. Diagnostic aids included the following:

1 At NARC, aerobic and anaerobic bacteriology, fungal culture (Silvanose et al., 1998), haematology (Samour et al., 1994), Chlamydia sp. antibody enzyme-linked immunosorbent assay (ELISA) (Ridascreen, r-Biopharm, Darmstadt, Germany) and Chlamydia sp. antigen ELISA

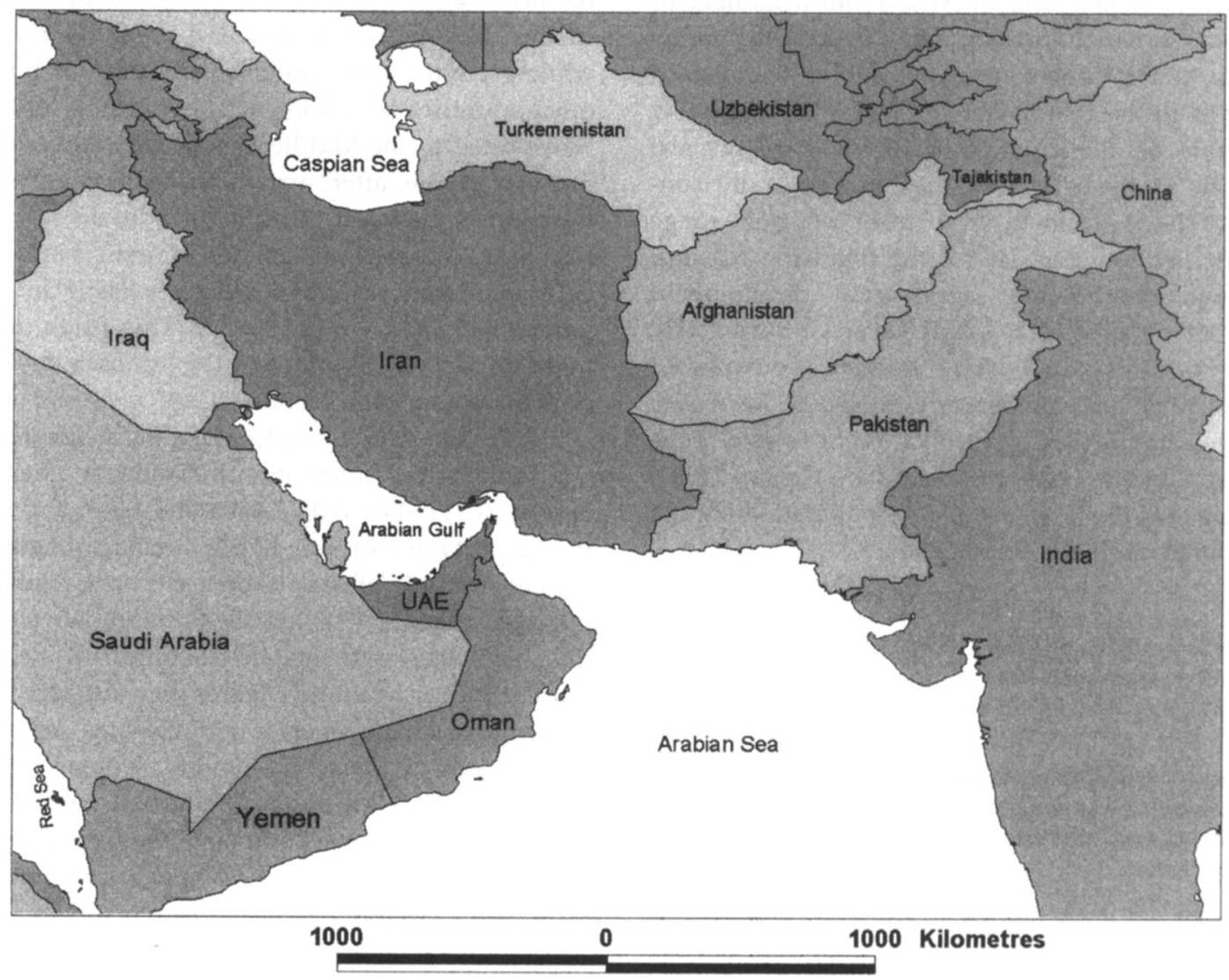

Fig. 1 Map of the Middle East showing the United Arab Emirates (UAE) in relation to surrounding countries (Iran, Afghanistan, Pakistan and Uzbekistan) where free-living houbara bustards are trapped before being transported to Gulf States. 
Table 1 Information (origin, year, examination country and location, numbers live and dead) on smuggled houbara bustards

\begin{tabular}{llllcc}
\hline Origin of birds & Year & Country examined & Site & No. live & No. dead \\
\hline Pakistan & $1992-94$ & UAE & 1 & 208 & 50 \\
Pakistan/Iran & 1997 & UAE & 2 & 54 & nd $^{*}$ \\
Pakistan & 1998 & UAE & 2 & 109 & 44 \\
Pakistan & 1996 & Pakistan & 3 & 105 & 43 \\
Pakistan & 1997 & Pakistan & 3 & 73 & 40 \\
Pakistan & 1998 & Pakistan & 3 & 47 & 2 \\
Total & & & & 596 & 179 \\
\hline
\end{tabular}

nd* These birds were euthanized because of a mixed infection with Chlamydia, PMV-1 and avian pox; post-mortem records were not available.

Site code: 1 = Al Ain Zoo quarantine unit, UAE; 2 = National Avian Research Center quarantine unit, UAE; 3 = Houbara Foundation International Rehabilitation Centre, Pakistan.
(Ideia, Dako Diagnostics Ltd, Ely, UK) according to the manufacturers' instructions.

2 At the Central Veterinary Research Laboratory (CVRL, Dubai, UAE) histopathology, virus isolation and PMV-1 haemagglutination inhibition (HI) serology (Wernery et al., 1992).

3 At the Central Veterinary Laboratory (CVL, New Haw, UK) virus isolation, virus serology (Bailey et al., 1996c) including PMV-2 and PMV-3 HI, avian pox agar gel precipitation (AGP), infectious bronchitis $\mathrm{HI}$, avian influenza AGP, avian pneumovirus and salmonella typing.

4 At the International Institute of Parasitologists (Jones et al., 1996) and MP Consultants International (Berkshire, UK) for endoparasite and blood parasite identification, respectively (Howlett et al., 1996).

\section{Estimation of flock mortality}

Mortality was estimated for eight imported flocks of houbara bustards (564 birds) after reviewing health records from previously published sources and from discussions with veterinary colleagues working in the Middle East. Additional seasonal mortality of 2900 birds from a rehabilitation centre in Pakistan, where multiple flocks were admitted from 1996 to 1998, was included for comparison.

Significance of diseases in relation to the rehabilitation of smuggled houbara bustards

A comprehensive list of infectious diseases confirmed in smuggled houbara bustards is presented in Table 4. The significance of each disease in relation to the quarantine and rehabilitation process was assessed using the following criteria:

\begin{tabular}{ll}
\hline Criterion & Significance \\
\hline $\begin{array}{c}\text { Flock mortality } \\
\text { post-transportation }\end{array}$ & $\begin{array}{l}\text { Significant, not } \\
\text { significant, unknown } \\
\text { Flock morbidity }\end{array}$ \\
$\begin{array}{l}\text { Significant, not } \\
\text { post-transportation } \\
\text { significant, unknown } \\
\text { country of importation* }\end{array}$ & $\begin{array}{l}\text { Significant, not } \\
\text { significant, unknown }\end{array}$ \\
$\begin{array}{c}\text { Zoonotic risk to humans } \\
\text { that come into contact }\end{array}$ & Yes, no, unknown \\
with houbara & \\
Health risk to falcons if & Significant, not \\
used as bagged quarry & significant, unknown \\
Health risk to free-living & Significant, not \\
houbara if released & significant, unknown \\
Treatment possible & Yes, no, unknown \\
during quarantine & \\
Disease carrier risk after & Significant, not \\
quarantinet & significant, unknown \\
\hline
\end{tabular}

* In terms of risk to large commercial flocks.

+ In terms of risk to other houbara bustards if rehabilitated birds are released into the wild or incorporated into captive flocks. Where data were not available for houbara bustards, published information from other avian species was used (Ritchie \& Carter, 1995).

\section{Health findings}

\section{The birds}

Data summarizing the origin, year, number of birds (live and dead), and the country and site where birds were examined are presented in Table 1. 


\section{Health monitoring results}

The results of health screening examinations on live and dead smuggled birds from 1992 to 1999 are presented in Table 2. The prevalence of the diseases (per cent) during this survey is also presented in Table 2. The most prevalent conditions detected in smuggled houbara bustards were PMV-1, avian pox, Chlamydia sp., aspergillosis and endoparasite infestations (Table 2). These conditions are discussed below.

\section{$P M V-1$}

The majority (55.9 per cent) of birds were exposed to PMV-1 as demonstrated by serology and PMV-1 virus was isolated from 4.1 per cent of samples derived from live and dead birds (Table 2). The disease is frequently associated with central nervous system signs (Ostrowski et al., 1995a; Bailey et al., 1997) and clinical outbreaks are an important cause of mortality after arrival in the UAE (Table 3 )

Avian pox

Avian pox lesions were apparent on 23.7 per cent of live birds examined during this survey (Table 2). The cutaneous form is most frequently seen and causes mild to moderate clinical signs (Ostrowski et al., 1995b; Bailey et al., 1996a), while the less commonly-seen diphtheroid (Plate 1) and septicaemic forms cause out- breaks of high morbidity and mortality (Samour et al., 1996; Table 3). The high prevalence of traumatic injuries (see below) probably facilitates the transmission of pox virus between birds.

\section{Aspergillosis}

Fungal granulomas in the respiratory tract of bustards yielding Aspergillus fumigatus was a common postmortem finding in 33.7 per cent of carcasses examined. Immunosuppression is known to play a major role in predisposing other species of birds to this disease (Wyatt \& Stewart, 1990), and the high prevalence in houbaras is probably associated with stress, overcrowding, malnutrition and exposure to other diseases.

\section{Chlamydia}

Twenty-five per cent and 50.8 per cent of birds were positive for Chlamydia sp. ELISA antigen and ELISA antibody, respectively. ELISA-positive birds were commonly infected with other viral and bacterial diseases, making it difficult to determine which agent was the primary pathogen. Clinical signs in positive birds included conjunctivitis, sinusitis, airsacculitis, pneumonia and hepatitis. Although the significance of Chlamydia sp. ELISA-positive houbara bustards has yet to be established, chlamydiosis is an important disease of captive houbara bustards (Greth et al., 1993).

Table 2 Results of health monitoring on live and dead smuggled houbara bustards listed in Table 1

\begin{tabular}{|c|c|c|c|c|}
\hline Disease or organism & Live or dead & Analysis & No. tested & No. positive (per cent) \\
\hline Chlamydia & Live & ELISA swab & 194 & $49(25.3)$ \\
\hline Chlamydia & Live & ELISA serum & 132 & $67(50.8)$ \\
\hline Salmonella & Dead & Cloacal swab & 41 & $11(26.8)$ \\
\hline Salmonella & Live & Cloacal swab & 93 & $2(2.2)$ \\
\hline Aspergillosis & Dead & PME & 163 & $55(33.7)$ \\
\hline Paramyxovirus 1 & Live + dead & Virus isolation & 121 & $5(4.1)$ \\
\hline Paramyxovirus 1 & Live & HI serum & 270 & $151(55.9)$ \\
\hline Paramyxovirus 2 & Live & HI serum & 126 & $5(3.9)$ \\
\hline Paramyxovirus 3 & Live & HI serum & 126 & $0(0)$ \\
\hline Avian pox & Live & Clinical exam & 585 & $139(23.7)$ \\
\hline Avian pox & Dead & PME & 161 & $19(11.8)$ \\
\hline Avian pox & Live & AGP serum & 146 & $11(7.5)$ \\
\hline Infectious bronchitis & Live & $\mathrm{HI}$ serum & 79 & $0(0)$ \\
\hline Avian influenza & Live & AGP serum & 79 & $0(0)$ \\
\hline Avian pneumovirus & Live & ELISA serum & 24 & $0(0)$ \\
\hline Avian reovirus & Live + dead & Virus isolation* & nd & nd \\
\hline Avian adenovirus & Dead & Virus isolation ${ }^{*}$ & nd & nd \\
\hline Trichomonas sp. & Live & Clinical exam & 491 & $76(15.5)$ \\
\hline Haemoproteus & Live & Blood smear & 165 & $90(54.5)$ \\
\hline Leucocytozoon & Live & Blood smear & 165 & $3(0.02)$ \\
\hline Endoparasites & Dead & PME & 93 & $34(36.5)$ \\
\hline
\end{tabular}

nd $=$ no data PME $=$ post-mortem examination.

* Reovirus and adenovirus were isolated from pooled samples submitted for virological screening from two flocks of birds in 1999 , but no data exist on the prevalence in individual birds. 
Table 3 Known causes of mortality of smuggled houbara bustard flocks in the Middle East and Pakistan

\begin{tabular}{llclll}
\hline Year & Country & No. birds & Mortality (per cent) & Cause & Source \\
\hline 1986 & UAE & 30 & 100 & PMV-1 & Bailey, 1998a \\
1993 & Bahrain & 123 & 100 & Avian pox & Samour et al., 1996 \\
1993 & UAE & 36 & 33 & PMV-1 & Bailey, 1998a \\
1994 & UAE & 22 & 77 & Aspergillosis & Bailey, unpublished \\
1995 & UAE & 200 & 50 & PMV-1 & Bailey, 1998a \\
1996 & Pakistan & 1400 & 25 & Multiple* & Bailey et al., 1997 \\
1997 & Pakistan & 1500 & 22 & Multiple* & Bailey et al., 1997; Bailey, 1998b \\
1998 & UAE & 34 & 59 & Avian pox & Bailey, unpublished \\
1998 & UAE & 24 & 25 & PMV-1 & Bailey, unpublished \\
1998 & UAE & 95 & 49 & Multiplet & Bailey, unpublished \\
\hline
\end{tabular}

* Includes pox, PMV-1, aspergillosis and secondary mixed bacterial infections.

tIncludes pox, PMV-1, reovirus, adenovirus, Psendontonas sp. and Salntonella spp.

\section{Endoparasites}

Parasites were found in the intestinal tract of 34 per cent of carcasses of birds that received no anthelmintic treatment between arrival at quarantine and death. Species identified included: Raillietina nyrai, Idiogenes sp., Ascometra vestita, Ascometra choriotidis, Hispaniolepis taeniatus, Mediorhynchus taeniatus and Centrorhynchus lancea (Jones et al., 1996). Although heavy endoparasite infestations are occasionally associated with mortality in individual smuggled houbara (Jones et al, 1996), the presence of parasites probably contributes to the overall debilitation shown by the birds.

\section{Other diseases}

Other infections associated with morbidity and mortality in smuggled bustards included: Trichomonas sp., Giardia sp., Clostridium spp. (C. botulinum, C. perfringens), Candida spp. (C.albicans, C. tropicalis), Salmonella spp. (S. typhinurium, S. arizona, S. reading), Pseudomonas aeruginosa and Pasteurella multocida. These agents were usually found in association with avian pox, PMV-1 or aspergillosis. Reovirus and adenovirus were isolated from live and dead birds in 1999, but there are insufficient data to provide an accurate idea of the prevalence of these conditions and further studies are currently underway. Serology also demonstrated antibodies to avian paramyxovirus type 2 (PMV-2) in live birds. The significance of reovirus, PMV-2 and adenovirus has yet to be determined, although PMV-2 has been associated with respiratory disease in a houbara bustard in Saudi Arabia (Ostrowski \& Combreau, 1995). These agents have all been associated with mortality of wild birds in quarantine stations in the UK (Ashton \& Cooper, 1989). Avian leucosis was found in 1 of 258 (0.4 per cent) houbara bustards examined at the CVRL between 1995 and 1998 (Kinne \& Wernery, unpublished data), but was not encountered during the current survey. This disease has been previously reported in an imported white-bellied bustard (Bailey et al., 1996b).

\section{Physical condition}

On arrival at rehabilitation and quarantine facilities, the birds were in poor body condition. In 1998, the mean bodyweight of birds within flocks on arrival at the NARC quarantine unit was $20-25$ percent below normal ranges (Bailey, unpublished observations). Eighteen per cent (41/228) of live birds examined had soft tissue traumatic injuries, mainly to the wing tip region. Houbara bustards are commonly trapped in snares set in gaps in brushwood fences adjacent to mustard fields in Pakistan (Plate 2), which often result in injuries or fractures to the limbs. Further injuries often arise during transportation when birds are crowded into a small space and the typical transport boxes in which houbara bustards are packed for ship-

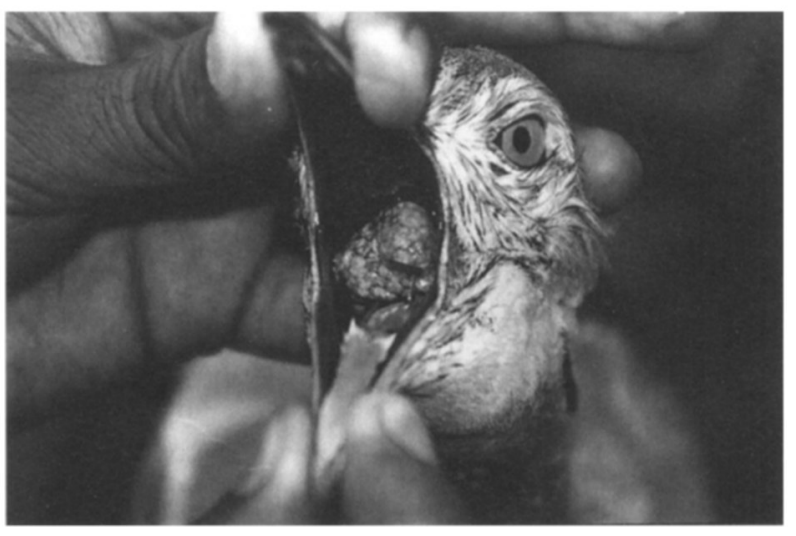

Plate 1 Viral diseases, such as avian pox in this bird (see large lesions in the oropharynx) are commonly seen in birds after confiscation and can cause devastating outbreaks of mortality (Tom Bailey). 


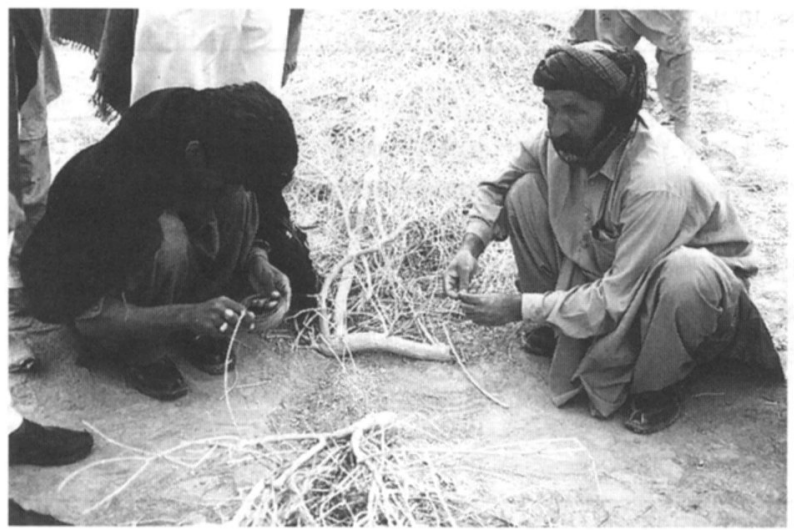

Plate 2 Houbara bustards are commonly trapped in snares set in gaps in brushwood fences adjacent to mustard fields in Pakistan (Tom Bailey).

ment into the Middle East are shown in Plate 3. Heavy louse infestations are also a common observation when birds arrive at rehabilitation and quarantine centres and again are probably an indication of the overall debilitation of the birds.

\section{Flock mortality}

The mortality of smuggled birds is often high, and Plate 4 shows dead birds collected from one confiscated consignment. Mortality data from 10 groups of birds are summarized in Table 3. Mortality ranged from 22 to 100 per cent. Information on the mortality at the rehabilitation centre in Pakistan is presented as the total number of birds admitted during a season, which included multiple flocks of various sizes. Information for Bahrain and the UAE concerns data on known individual flocks.

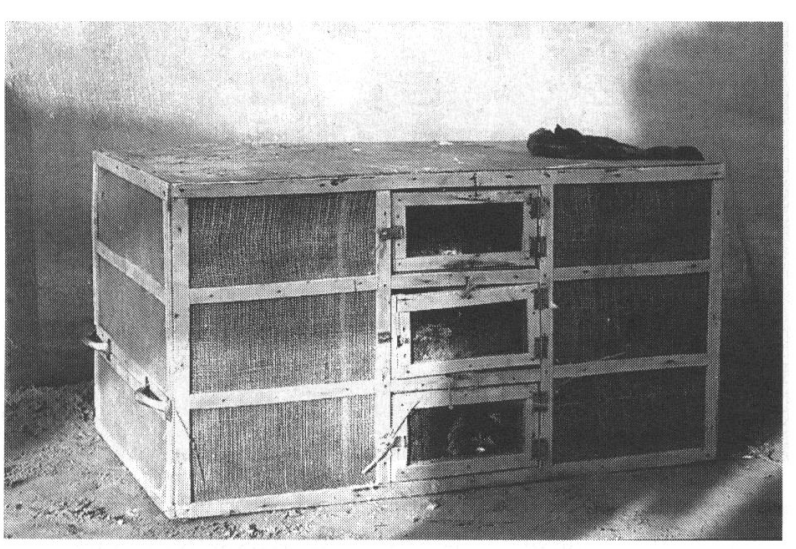

Plate 3 Typical transport boxes in which houbara bustards are packed for shipment into the Middle East (Tom Bailey).

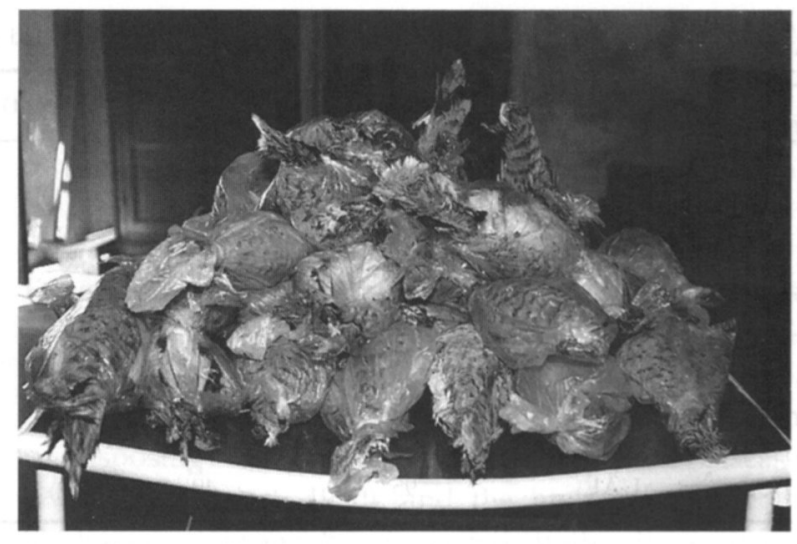

Plate 4 The mortality of transported birds is often high; these birds were from consignments confiscated in Pakistan (Tom Bailey).

\section{Significance of diseases}

A comprehensive list of diseases confirmed in smuggled houbara bustards and their significance to rehabilitation projects is presented in Table 4 . Viral diseases represent the clearest health threat to smuggled houbara bustards presented for rehabilitation, because of the inability to treat infections, the lack of knowledge concerning recovery from infection and the potential for recovered, but latently infected, birds to shed the virus and to infect other birds by either vertical or horizontal transmission. In addition, although vaccination regimens have been established for PMV-1 in houbara bustards using commercially available poultry preparations (Bailey, 1998a), effective vaccination regimens have not been determined for the other viral diseases. Consequently, virological screening is an important component of assessing and monitoring health before release into the wild or incorporation into captive breeding projects. The zoonotic potential of chlamydiosis and salmonellosis should be considered by those involved in the rehabilitation process, but may also be of importance to falconers and their hunting falcons, which consume dead birds used in the training process.

\section{Discussion}

The trade and movement of live non-domesticated birds between countries are well-known factors in spreading avian pathogens (Ashton \& Cooper, 1989; Clubb \& Rosskopf, 1996; Shortridge \& Burrows, 1997). Reviews of disease outbreaks from quarantine stations indicate that many birds are diseased before shipment, acquire infections during transport, or have increased 
susceptibility to disease following shipment (Wolff, 1996). The nature of the trade of houbara bustards in which they are trapped in the wild, housed in overcrowded unhygienic and cramped cages, exposed to the rigours of transit and climatic extremes, malnourished and damaged by traumatic injuries means that a high mortality is almost inevitable in the current survey, no single disease entity was responsible for the majority of morbidity or mortality seen in these smuggled birds; instead, the birds presented with a 'cocktail' of diseases. The susceptibility of imported houbara bustards under conditions of stress to viral diseases concurs with investigations on other imported wild avian species (Ashton, 1984; Shortridge et al., 1991; Doyle, 1997; Shortridge \& Burrows, 1997). A similar trade in East African bustard species also exists (Goriup, 1987), and disease is an important mortality factor in these species when they arrive in the Middle East (Bailey et al., 1996a,b; Nicholls et al., 1996).

Consequently, the mortality of houbara bustards as a direct result of this trade is large, ranging from 22 to 100 percent of smuggled birds even after they have been presented to facilities where they receive medical treatment. It is probable that the mortality of birds is higher in birds that continue through the trade cycle because of the lack of any medical attention. Even if a conservative figure of 25 percent mortality is used, based on data from the largest rehabilitation project, and using the estimate of 4000-7000 birds that are suspected to be involved in the trade from Pakistan alone, then in excess of 1250-1750 houbara bustards die directly as a result of disease. Mortality after capture and before transportation also needs to be considered, but because of the secrecy of this trade accurate infor-

Table 4 Infectious diseases of smuggled houbara bustards and their significance for rehabilitation projects

\begin{tabular}{|c|c|c|c|c|c|c|c|c|}
\hline \multirow[b]{2}{*}{ Category } & \multirow[b]{2}{*}{ Agent } & \multicolumn{7}{|c|}{ Significance } \\
\hline & & $\begin{array}{l}\text { Flock } \\
\text { mortality }\end{array}$ & $\begin{array}{l}\text { Flock } \\
\text { morbidity }\end{array}$ & $\begin{array}{l}\text { Poultry } \\
\text { risk }\end{array}$ & $\begin{array}{l}\text { Zoonotic } \\
\text { risk }\end{array}$ & $\begin{array}{l}\text { Falcon } \\
\text { risk }\end{array}$ & Treatment & $\begin{array}{l}\text { Carrier } \\
\text { status }\end{array}$ \\
\hline \multirow[t]{6}{*}{ Viral } & $\begin{array}{l}\text { Paramyxovirus } \\
\text { type } 1\end{array}$ & S & $\mathrm{S}$ & $\mathrm{S}$ & No & $\mathrm{S}$ & $\mathrm{No}^{*}$ & $\mathrm{~s}$ \\
\hline & $\begin{array}{l}\text { Paramyxovirus } \\
\text { type } 2\end{array}$ & UK & UK & $\mathrm{S}$ & No & $\mathrm{S}$ & Not & $S$ \\
\hline & Avian pox & $\mathrm{S}$ & $S$ & $\mathrm{~S}$ & No & UK & Not & $\mathrm{S}$ \\
\hline & Avian leucosis & NS & UK & NS & No & UK & No & $S$ \\
\hline & Avian reovirus & UK & UK & UK & No & UK & Not & $S$ \\
\hline & Adenovirus & UK & UK & UK & No & UK & Not & S \\
\hline \multirow[t]{2}{*}{ Fungal } & $\begin{array}{l}\text { Aspergillus } \\
\text { fumigatus }\end{array}$ & $\mathrm{s}$ & $\mathrm{S}$ & NS & No & NS & Yes & NS \\
\hline & Candida albicans & NS & NS & NS & No & UK & Yes & NS \\
\hline \multirow[t]{5}{*}{ Bacterial } & $\begin{array}{l}\text { Chlamydia } \\
\text { psittacif }\end{array}$ & NS & $\mathrm{S}$ & $\mathrm{S}$ & Yes & $\mathrm{S}$ & Yes & $S$ \\
\hline & Salnonella sp. & NS & $S$ & NS & Yes & $\mathrm{S}$ & Yes & $S$ \\
\hline & $\begin{array}{l}\text { Pseudomonas } \\
\text { aeruginosa }\end{array}$ & NS & $\mathrm{S}$ & NS & No & $\mathrm{S}$ & Yes & NS \\
\hline & $\begin{array}{l}\text { Clostridium } \\
\text { perfringens }\end{array}$ & NS & NS & NS & No & $\mathrm{S}$ & Yes & NS \\
\hline & $\begin{array}{l}\text { Pasteurella } \\
\text { multocida }\end{array}$ & NS & NS & NS & No & $\mathrm{S}$ & Yes & NS \\
\hline \multirow[t]{4}{*}{ Parasitic (protozoa) } & Trichomonas sp. & NS & $S$ & NS & No & $\mathrm{S}$ & Yes & NS \\
\hline & Giardia sp. & NS & NS & NS & Yes & $\mathrm{S}$ & Yes & NS \\
\hline & Haemoproteus sp. & NS & NS & NS & No & NS & Yes & NS \\
\hline & Leucocytozoon sp. & NS & NS & NS & No & NS & Yes & NS \\
\hline Parasitic (endoparasites) & Results§ & NS & $\mathrm{S}$ & NS & No & NS & Yes & UK \\
\hline Parasitic (ectoparasites) & Results§ & NS & $S$ & NS & No & NS & Yes & UK \\
\hline
\end{tabular}

UK = unknown; NS = not significant; $S=$ significant.

* Effective vaccines are available.

+ Vaccines are available, but efficacy in houbara bustards has not been determined.

$\ddagger$ Reported in captive birds (Greth et al., 1993).

$\S$ Species of parasites are listed in the results. 
mation is scarce. Interviews were conducted with houbara trappers in 1996 in Pakistan (Bailey, unpublished data) and while many said they lost no birds, some admitted that they lost one- to two-thirds of birds before they were sold on to the dealers. The data presented in this paper probably represent the tip of the houbara bustard iceberg'. Only a small proportion of smuggled birds is confiscated and comes to the attention of scientific and conservation agencies such as NARC. Clearly, this trade should be considered by those interested in the conservation and sustainable use of this species because it represents:

- A wastage of free-living houbara bustard populations. A potential disease risk to falcons when these birds are used as 'bagged' quarry or if released by falconers to supplement birds in hunting grounds.

- A potential disease risk to free-living houbara bustard populations when confiscated birds are released by wildlife agencies without health monitoring and medical treatment.

- A disease risk to captive-breeding bustard populations when confiscated birds are incorporated into official programmes without medical screening.

- A potential threat to human health from pathogens such as salmonellae and Chlanydia sp.

- An important health risk to poultry production in the Middle East.

\section{Recommendations}

Agencies in Pakistan and the Middle East have started to address this problem by confiscating consignments of houbara bustards. However, the health of these birds must be considered in relation to their rehabilitation and eventual release into natural habitats or integration into captive flocks (Ostrowski \& Combreau, 1995; White \& Morzenti, 1997; IUCN, 2000). Whilst the release of birds infected with aspergillosis or trichomoniasis may result in a bird that fails to survive the rigours of the wild, especially the long migration that houbara undertake (Combreau et al., 1999), the release of birds infected with viral diseases could have more serious implications for free-living birds that may not have been exposed to these diseases. Consequently, the benefits of releasing rehabilitated birds should be weighed against the possible adverse effects of accidental disease introduction before deciding whether such interventions are justified (Cunningham, 1996; IUCN, 2000). Our findings are relevant to other rehabilitation projects working with confiscated animals that may have been exposed to infectious diseases and emphasize the importance of veterinary support for these programmes (Greenwood, 1996). We therefore recommend the following initiatives:
Table 5 Recommended minimum health screening protocols for smuggled houbara bustards on entry to quarantine units

\begin{tabular}{|c|c|}
\hline Test & Sample \\
\hline Chlamydia & Choanal swab and sera \\
\hline Virus isolation & Choanal+cloacal swabs \\
\hline Haematology & Full haematology and blood smear \\
\hline PMV-1 serology & Serum \\
\hline Bacteriology & Cloacal swab \\
\hline Parasitology & Faecal sample and oropharyngeal swab \\
\hline
\end{tabular}

- Confiscated birds be submitted to centres where they can be quarantined, undergo health screening (Table 5), and be provided with appropriate husbandry and medical care.

- Birds destined for release be given, as a minimum, (1) a pre-release clinical veterinary examination and (2) more comprehensive health screening, depending on the resources available to the agencies involved in rehabilitation (Table 6).

- Investigations be initiated to monitor the subsequent health of houbara bustards that have been exposed to and have survived avian viral infections.

- Studies be undertaken to establish effective vaccination protocols against the common viral pathogens of houbara bustards.

- All released birds be uniquely identified with a ring or identification microchip, while some rehabilitated birds be released with radio and satellite telemetry so that post-release data can be collected.

- Health monitoring of free-living populations be initiated to determine the range of diseases, especially those caused by viruses to which houbara bustards are naturally exposed.

Table 6 Recommended health screening protocols for smuggled houbara bustards surviving quarantine and before release

\begin{tabular}{|c|c|c|}
\hline Test & Sample & $\begin{array}{l}\text { Acceptable criteria } \\
\text { for release }\end{array}$ \\
\hline \multicolumn{3}{|l|}{ Essential database } \\
\hline Virus isolation & $\begin{array}{l}\text { Choanal }+ \\
\text { cloacal swabs }\end{array}$ & Negative \\
\hline Haematology & $\begin{array}{l}\text { Whole blood } \\
\text { (EDTA) }\end{array}$ & $\begin{array}{l}\text { Within normal } \\
\text { ranges }\end{array}$ \\
\hline Chlamydia detection & Choanal swab & $\begin{array}{l}\text { Negative antigen } \\
\text { ELISA }\end{array}$ \\
\hline Bacteriology & Cloacal swab & $\begin{array}{l}\text { Negative for } \\
\text { pathogens }\end{array}$ \\
\hline \multicolumn{3}{|c|}{ Optional (if compatible with time resources) } \\
\hline Endoscopy & $\begin{array}{l}\text { Internal } \\
\text { examination }\end{array}$ & $\begin{array}{l}\text { No abnormalities } \\
\text { observed }\end{array}$ \\
\hline Blood chemistry & $\begin{array}{l}\text { Whole blood } \\
\text { (Heparin) }\end{array}$ & $\begin{array}{l}\text { Within normal } \\
\text { ranges }\end{array}$ \\
\hline
\end{tabular}




\section{Acknowledgements}

We thank H. H. Sheikh Khalifa bin Zayed Al Nahyan, President of the ERWDA Board of Directors, H. H. Sheikh Hamdan bin Zayed Al Nahyan, Vice President of the ERWDA and Mr M. Al Bowardi, ERWDA Managing Director, for their support of the veterinary science programme of NARC. We thank Mr A. Azur, Mr D. Tadena, Mr M. Nafees Miss J. Howlett, Miss N Hajjoubtaba and Mr D. Gliddon from ERWDA, for their assistance with this project. We also thank our colleagues in the Pakistan Customs Department and Brigadier M. Ahmed, Mr H. Rashid and Mr S. Nadeem from the Houbara Foundation International, Pakistan, for their collaboration.

\section{References}

Ahmed, M. (1997) Houbara Foundation International Pakistan. Arabian Wildlife, 3, 13-15.

Anon. (1993) Cabinet orders houbara ban. Emirates News, 16 November.

Ashton, W.L.G. (1984) The risks and problems connected with the import and export of captive birds. British Veterinary Journal, 140, 317-327.

Ashton, W.L.G. \& Cooper, J.E. (1989) Exclusion, elimination and control of avian pathogens. In Disease and Threatened Birds (ed. J. E. Cooper), pp. 31-38. Cambridge, UK. International Council for Bird Preservation Technical Publications No. 10.

Bailey, T.A. (1998a) Disease, therapeutics and preventive medicine in avian captive breeding programmes: the example of the houbara bustard, Chlamydotis undulata macqueenii. Unpublished PhD thesis, Durrell Institute of Conservation and Ecology, University of Kent, UK.

Bailey, T.A. (1998b) Summary of Health Recommendations for the Houbara Bustard Rehabilitation Center in Rahim yar Khan, Pakistan, March 1998. National Avian Research Center Internal Research Report.

Bailey, T.A., Samour, J.H., Naldo, J., Howlett, J. \& Tarik, M. (1996a) Causes of morbidity in bustards in the United Arab Emirates. Avian Diseases, 40, 121-129.

Bailey, T.A., Nicholls, P.K., Samour, J.H., Naldo, J., Wernery, U. \& Howlett, J. (1996b) Post-mortem findings of bustards in the United Arab Emirates. Avian Diseases, 40, 296-305.

Bailey, T.A., Wernery, U., Gough, R.E., Manvell, R. \& Samour, J.H. (1996c) Serological survey of houbara bustards (Chlamydotis undulata macqueenii) in the UAE for antibodies against some avian viruses. Veterinary Record, 139, $238-239$.

Bailey, T.A., Combreau, O. \& Ahmed, M. (1997) A Report on the Rehabilitation and Research Center of the Houbara Foundation International, Pakistan, March 1997. National Avian Research Center Internal Research Report.

Clubb, S.L. \& Rosskopf, W.J. (1996) History of importation of birds into the United States. In Diseases of Cage and Aviary Birds (eds W. Rosskopf and R. Woerpel), pp. 904-914. Williams and Wilkins, Baltimore, MD.
Collar, N. (1996) Bustards. In Handbook of Bitds of the World. Vol 3. Hoatzin to Auks (eds J. Del Hoyo, A. Elliot and J. Sargatal), pp. 240-273. Lynx Editions, Barcelona.

Combreau, O., Launay, F., Al Bowardi, M. \& Gubin, B. (1999) Outward migration of houbara bustards from two breeding areas in Kazkahstan. The Condor, 101, 259-265.

Cunningham, A.A. (1996) Disease risks of wildlife translocations. Conservation Biology, 10, 349-353.

Doyle, K.A. (1997) Avian quarantine. Australian Veterinary Journal, 75, 645-647.

Goriup, P.D. (1987) Selling out East Africa's bustards. SWARA, Joumal of the East African Wildlife Society, 10, $20-22$.

Goriup, P.D. (1997) The world status of the houbara bustard Chlamydotis undulata. Bird Conservation International, 7, 373-397.

Greenwood, A. (1996) Veterinary support for in-situ avian conservation programmes. Bird Conservation International, 6, 285-292.

Greth, A., Andral, B., Gerberman, H., Vassert, M., Gerlach, H. \& Launay, F. (1993) Chlamydiosis in a captive group of houbara bustards (Chlamydotis undulata). Avian Diseases, 37, 1117-1120.

Howlett, J.C., Samour, J.H., D’Aloia, M.-A., Bailey, T.A. \& Naldo, J. (1996) Haemoproteus in the houbara bustard (Chlamydotis undulata maqueenii) and the rufous-crested bustard (Eupodotis ruficrista) in the United Arab Emirates. Avian Pathology, 25, 49-55.

IUCN (1996) 1996 IUCN Red List of Threatened Animals. IUCN, Gland, Switzerland.

IUCN (2000) IUCN Guidelines for the Placement of Confiscated Live Animals. IUCN/SSC Re-introduction Specialist Group. IUCN, Gland, Switzerland.

Jones, A., Bailey, T.A., Nicholls, P.K., Samour, J. \& Naldo, J (1996) Cestode and acanthalocephalan infestations in captive bustards: new host and location records, pathology, control and preventive medicine. Journal of Zoo and Wildife Medicine, 27, 201-208.

Launay, F., Combreau, O. \& Al Bowardi, M. (1999) Annual migration of houbara bustard Chlamydotis undulata macqueenii from the United Arab Emirates. Bird Conseroation International, 9, 155-161.

Nicholls, P.K., Bailey, T.A., Gibbons, L.M., Jones, A., Naldo, J. \& Samour, J. (1996) Parasitic infestation of a flock of rufous-crested bustards (Eupodotis ruficrista). Journal of Zoo and Wildlife Medicine, 26, 590-596.

Ostrowski, S. \& Combreau, O. (1995) Disease as a consideration in translocating and reintroducing houbara bustards. In Restoration of Bustard Populations: Captive Breeding, Release, Monitoring and Habitat Management (eds M. Heezik and P.J. Seddon), Pp. 61-64. National Wildlife Research Center, National Commission for Wildlife Conservation and Development Publication No. 27, Riyadh, Kingdom of Saudi Arabia.

Ostrowski, S., Ancrenaz, M., Saint-Jalme, M. \& Greth, A. (1995a) Concurrent avian pox and Newcastle disease in a houbara bustard (Chlamydotis undulata). Avian Pathology, 24, 573-577.

Ostrowski, S., Dorrestein, G.M., Ancrenaz, M. \& Saint-Jalme, M. (1995b) Debilitating cutaneous poxvirus lesions on two captive houbara bustards (Chlamydotis undulata). Avian Diseases, 39, 907-911. 
Ritchie, B.W. \& Carter, K. (1995) Avian Viruses: Function and Control. Wingers Publishing, Inc., Lake Worth, FL.

Samour, J.H., Howlett, J.C., Hart, M.G., Bailey, T.A., Naldo, J. \& D'Aloia, M.-A. (1994) Normal haematology of the houbara bustard (Chlamydotis undulata macqueenii). Comparative Haematology International, 4, 198-202.

Samour, J., Kaaden, O.-R., Wernery, U. \& Bailey, T.A. (1996) An epornitic of avian pox in houbara bustards. Journal of Veterinary Medicine, 43, 287-292.

Shortridge, K.F. \& Burrows, D. (1997) Prevention of entry of avian influenza and paramyxoviruses into an ornithological collection. Veterinary Record, 140, 373-374.

Shortridge, K.F., Burrows, D. \& Erdie, J. (1991) Potential danger of avian paramyxovirus type 3 to ornithological collections. Veterinary Record, 129, 363-364.

Silvanose, C., Samour, J., Naldo, J. \& Bailey, T.A. (1998) Intestinal protozoa and associated bacteria in captive bustards in the United Arab Emirates. Avian Pathology, 28, 94-97.

Wernery, U., Remple, J.D., Neumann, D.J., Alexander, D.J., Manvell, R.J. \& Kaaden, O.R. (1992) Avian paramyxovirus serotype 1 (Newcastle disease virus) infections in falcons. Journal of Veterinary Medicine, 39, 153-158.

White, J. \& Morzenti, A. (1997) Current guidelines for the release of native free-ranging birds Proceedings of the Association of Avian Veterinarians, pp. 67-73.

Wolff, P.L. (1996) Husbandry practices employed by private aviculturalists, bird markets and zoo collections, which may be conducive to fostering infectious diseases. Revue Scientifique et Technique. Office International des Epizooties, $15,55-71$.

Wyatt, R. \& Stewart, R.G. (1990) Fungal diseases. In Poultry Diseases (ed. F.T.W. Jordan), pp. 216-225. Bailliere Tindall, London.

\section{Biographical sketches}

1. National Avian Research Center (NARC). The NARC is based in the Emirate of Abu Dhabi in the UAE and is a Center of the Environmental Research and Wildlife Development Agency. NARC's flagship species are the houbara bustard and saker falcon. The Center promotes the ecologically sustainable utilization and maintenance of the houbara bustard and saker falcon, believing that working with these flagship species will, in the long term, help to ensure the conservation of desert wildlife in general.

2. Central Veterinary Research Laboratory (CVRL). The CVRL was founded by $\mathrm{H}$. H. General Sheikh Mohammed Bin Rashid Al Maktoum in 1985 and operates as a government veterinary centre, responsible for diagnosis of diseases in all animal species, especially camels, falcons and horses. The CVRL is internationally recognized for serological testing of equine notifiable diseases for the Gulf region.

3. Central Veterinary Laboratory. The international role of the Avian Virology unit of the Central Veterinary Laboratory, UK, includes designation as OIE, FAO and EU reference laboratory for Newcastle disease and avian influenza and viral diseases of poultry. Diagnostic testing by tissue culture, embryonated eggs, electron microscopy, serology and molecular techniques is carried out. Projects involving raptors, ratites, waterfowl, gamebirds, psittaciformes, bustards, penguins, reptiles and amphibia have been undertaken. 